\title{
Some Effects of a Low Sodium Diet High in Potassium on the Renin-Angiotensin System and Plasma Electrolyte Concentrations in Normal Dogs
}

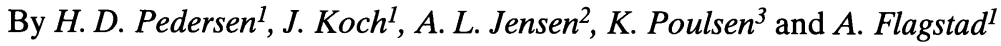 \\ ${ }^{1}$ Small Anımal Hospital and ${ }^{2}$ Central Laboratory, Department of Clınical Studies, ${ }^{3}$ Department of Anatomy \\ and Physıology, The Royal Veterinary and Agricultural Unıversity, Frederıksberg, Denmark.
}

\begin{abstract}
Pedersen, H. D., J. Koch, A. L. Jensen, K. Poulsen, A. Flagstad: Some effects of a low sodium diet high in potassium on the renin-angiotensin system and plasma electolyte concentrations in normal dogs. Acta vet. scand. 1994, 35, 133-140. - Eight normal male Beagle dogs received $0.7 \mathrm{mmol} \mathrm{Na}^{+} / \mathrm{kg} /$ day for 5 weeks and $4.0 \mathrm{mmol} \mathrm{Na}^{+} / \mathrm{kg} /$ day in one 3 week control period preceding and another similar period following the low sodium period. The dogs received $6.8 \mathrm{mmol} \mathrm{K} / \mathrm{kg} /$ day throughout the study.

The median plasma renin activity (PRA) and plasma aldosterone concentration (PAC) were higher in the low sodium period than in the following control period $(0.67$ versus $0.28 \mathrm{ng} / \mathrm{ml} / \mathrm{h}, \mathrm{p}<0.0001)$ and (204 versus $31 \mathrm{pg} / \mathrm{ml}, \mathrm{p}<0.0001)$. PRA and PAC quickly stabilized on a new steady level in response to altered intake of sodium chloride. The angiotensin-converting enzyme (ACE) actıvity was not changed by the altered intake of sodium chloride.

The plasma concentrations of sodium and chloride were increased during the low sodium period. This could be due to an indirect effect of the high potassium intake of the dogs. Potassium leads to an increased secretion of aldosterone and thereby to an increased retention of sodium and chloride in the kıdney. The possible implications of a high potassium content in a low sodium diet are discussed.
\end{abstract}

Beagle dogs; physiology; plasma renin activity; plasma aldosterone concentration; angiotensin-converting enzyme activity; chloride; magnesium.

\section{Introduction}

A low sodium diet is often used as an adjunctive treatment in dogs with congestive heart failure (CHF) (Ross 1984). Sodium restriction helps by reducing the retention of salt and water (Pensinger 1964) caused mainly by aldosterone and angiotensin II (Ang II), a component of the renin-angiotensin system (RAS). Increased activity of the RAS is a major part of the pathophysiology of CHF (Watkins et al. 1976). Therefore, it seems paradoxical that sodium restriction acts as a very potent stimulus for the RAS. Sodium restriction is known to cause an increase in plasma renin activity (PRA), Ang I, Ang II and plasma aldosterone concentration (PAC) (Krieger et al. 1990). A recent study in rats also showed an increase in serum angiotensin-converting enzyme (ACE) activity in response to strict sodium restriction (Fox et al. 1992). Knowing that sodium restriction has a major impact on the RAS makes it important to know the sodium intake of the patient when evaluating the different parameters within the RAS.

Studies focused on the impact of low sodium diets on the RAS are scarce in the veterinary 
literature. The purpose of this study was to assess the effect of a clinically relevant low sodium diet on PRA, PAC and serum ACE activity in normal dogs. In a clinical situation, it is important to know the time it takes for these parameters to reach a new steady state after introducing a diet with a certain sodium content, for instance a low sodium diet. The study was therefore designed to give information concerning the numeric increase as well as the long term dynamics of PRA, PAC and ACE activity.

Practically all dogs with CHF are treated with a diuretic. Treating heart failure in dogs with furosemide has been shown to cause a reduction in the plasma concentration of potassium (Cobb \& Michell 1992). A high potassium content in low sodium diets would be desirable in helping to avoid hypokalaemia in such patients. It was decided in this study to evaluate the effects of a low sodium diet with a high potassium content.

\section{Methods}

\section{Dogs and protocol}

Eight clinically healthy non-related male Beagle dogs aged 1 to $1 \frac{1}{2}$ years old and weighing $12-16 \mathrm{~kg}$ (mean $14 \mathrm{~kg}$ ) were included in the study. The dogs were housed individually in their usual cages and were fed once a day between 9.00 and 10.30 a.m. according to the equation (Legrand-Defretin 1993): kcal metabolisable energy per dog per day $=125$ (bodyweight) $^{075}$. A minor weight loss during the initial control period, probably caused by a high level of activity, promoted a $10 \%$ increase in the daily allowances for the rest of the study to ensure a stable body weight. Each dog ate all of the provided food each day. The dogs were offered tap water ad libitum containing approximately $0.2 \mathrm{mmol}$ potassium and $1.3 \mathrm{mmol}$ sodium per litre. The dogs re- ceived no drugs 2 weeks prior to or during the study. Furthermore, no abnormalities were revealed on routine hematological and biochemical analyses of the dogs prior to the experiment.

The feeding experiment consisted of 3 periods of 3, 5 and 3 weeks duration respectively. Initially, the dogs were fed a canned control diet for 3 weeks, then a canned low sodium diet for 5 weeks and finally the canned control diet again for 3 weeks. The control diet was made by adding sodium chloride to half the batch of low sodium diet just before it was canned. Hence only the content of sodium chloride differed between the 2 diets. This protocol provided each dog with $4.0,0.7$ and $4.0 \mathrm{mmol}$ $\mathrm{Na}+/ \mathrm{kg} /$ day in the first, second and third period, respectively (not including sodium in the drinking water, approximately $0,08 \mathrm{mmol}$ $\mathrm{Na}^{+} / \mathrm{kg} /$ day). The diets provided each dog

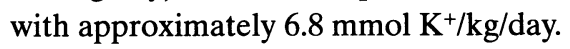

\section{Sample collection}

Blood samples were collected by jugular venipuncture at the end of the first control period and every 7 days for the rest of the trial. Additionally, PRA and PAC were measured 3 days into the low sodium period and 2 days into the following control period. All samples were taken between 9.00 and 10.00 a.m. after overnight fast. Great care was taken to minimize stress during the blood sampling procedure and all the blood samples were drawn by the same veterinarian. Blood for PRA and PAC determination was transferred to iced EDTAcontaining tubes (Becton-Dickinson) immediately and centrifuged at $4^{\circ} \mathrm{C}$ within $1 \mathrm{~h}$. Serum was also separated within $1 \mathrm{~h}$. Plasma and serum were kept at $-20^{\circ} \mathrm{C}$ until the end of the trial. The samples were analysed for PRA, PAC, ACE-activity in serum and for the concentration of sodium, potassium, chloride, calcium and magnesium in plasma. 


\section{Analytical procedures}

PRA was assayed according to the radioimmunoassay of Poulsen \& Jørgensen (1974). The PAC was determined with a RIA-kit (Coat-A-Count ${ }^{\circledR}$, Diagnostic Products Corporation). The ACE-activity in serum was measured spectrophotometrically with a kit (Angiotensin Converting Enzyme (ACE) ${ }^{\circledR}$, Sigma) applied to a Cobas Fara ${ }^{\circledR}$ centrifugal analyzer (Roche) as described by Jensen \& Koch (1992). The concentrations of sodium, potassium, chloride, calcium and magnesium in plasma were measured by the electrolyte module of the Cobas Fara ${ }^{\circledR}$ centrifugal analyzer. Each component was analysed in one run, and all measurements were done in duplicate.

\section{Statistical analysis}

Wilcoxon signed rank test for paired observations was used to compare the values of the different components before and after each of the 2 changes in sodium intake. Wilcoxon rank sum test was used to compare pooled data from the low sodium period with pooled data from the following control period. ANOVA for repeated measurements was used to look for changes within the low sodium period and within the following control period. The null hypothesis was rejected at $\mathrm{p}$ $<0.05$. Data are presented as medians and 25/75 percentiles.

\section{Results}

Fig. 1 summarizes the changes in PRA, PAC and ACE-activity in serum during the feeding trial. Introducing the low sodium diet caused no change in PRA $(\mathrm{p}=0.55)$, but withdrawing the low sodium diet after 5 weeks decreased PRA significantly $(p=0.008)$. The median PRA during the low sodium period was higher than during the following control

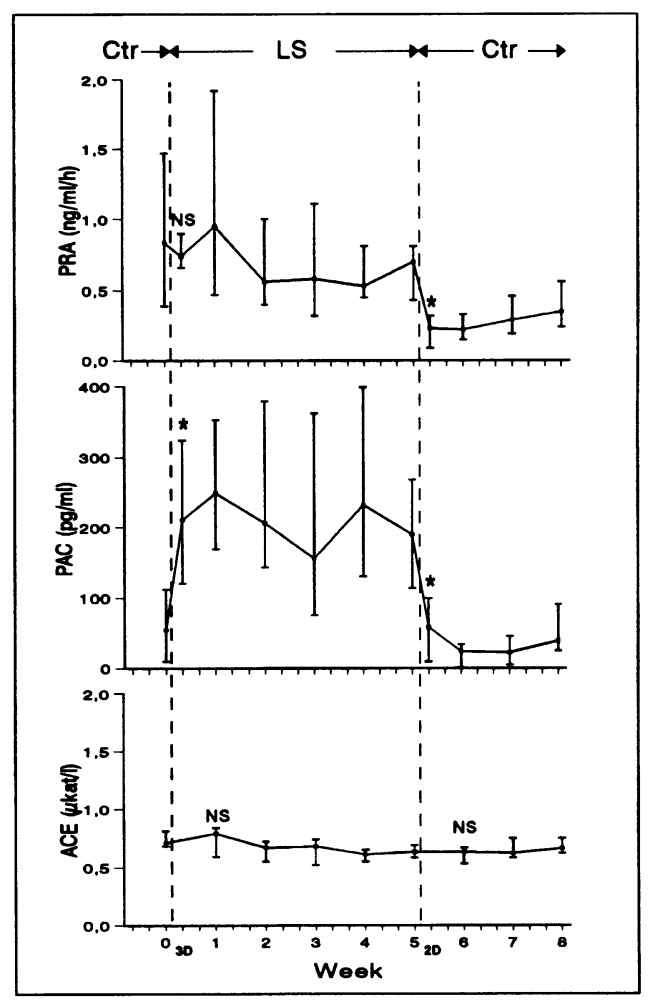

Figure 1. Plasma renın actıvity (PRA), plasma aldosterone concentration (PAC) and serum angiotensin-converting enzyme activity (ACE) in 8 normal Beagle dogs fed a control diet (Ctr) for 3 weeks, a low sodium diet (LS) for 5 weeks and the control diet again for 3 weeks Values are medians and $25 / 75$ percentiles. The first values after each change in diet were compared to the values obtained before the diet-change. $*=$ Significant change $(p \leq 0,05), N S$ $=$ Non-significant changes $(\mathrm{p}>0,05) 3 \mathrm{D}$ and $2 \mathrm{D}$ indicates 3 respectively 2 days after the diet changes.

period $(0.67 \mathrm{ng} / \mathrm{ml} / \mathrm{h}$ and $0.28 \mathrm{ng} / \mathrm{ml} / \mathrm{h}$, $\mathrm{p}<0.0001)$. PAC increased in response to the decreased sodium intake $(\mathrm{p}=0.008)$ and decreased when the control diet resumed $(\mathrm{p}=$ 0.008). Accordingly, the median PAC was higher during the low sodium period than during the following control period $(204 \mathrm{pg} / \mathrm{ml}$ and $31 \mathrm{pg} / \mathrm{ml}, \mathrm{p}<0.0001)$. Both PRA and PAC 


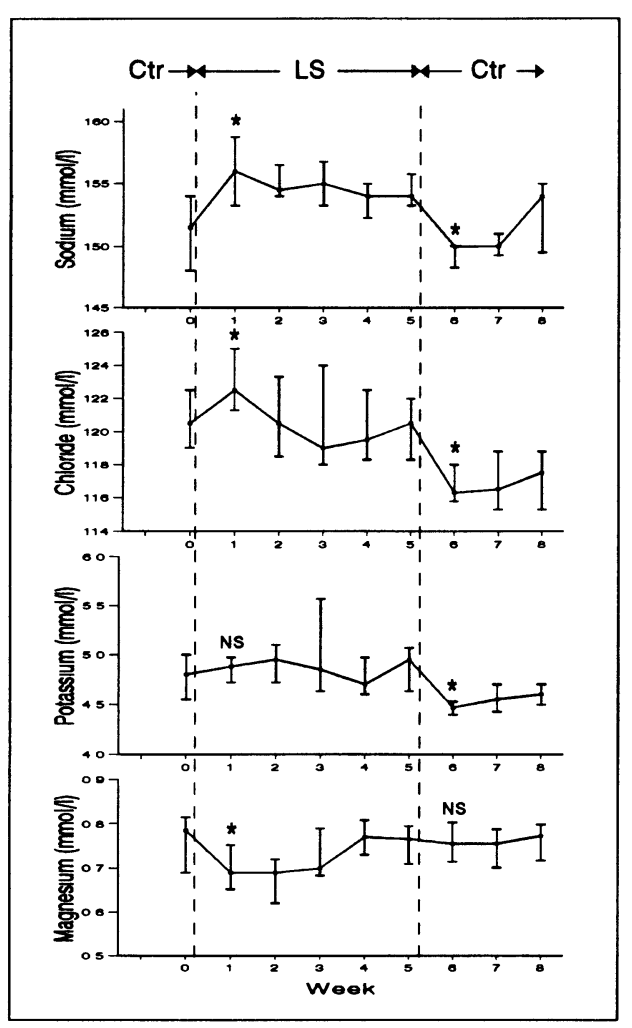

Figure 2 Plasma concentrations of sodium, chloride, potassium and magnesium in 8 normal Beagle dogs fed a control diet (Ctr) for 3 weeks, a low sodium diet (LS) for 5 weeks and the control diet again for 3 weeks. Values are medians and 25/75 percent1les. The values one week after both changes in diet were compared to the values obtained before the diet-change. ${ }^{*}=$ Significant changes $(p \leq 0,05), N S=$ Non-significant changes ( $p>0,05)$.

were constant during the 5 week low sodium period $(\mathrm{p}=0.17$ and $\mathrm{p}=0.18)$ and during the following 3 week control period ( $p=0.18$ and $\mathrm{p}=0.06)$. The ACE-activity in serum was unchanged at both the first and the second change in sodium intake ( $p=0.69$ and 0.84 ). The median ACE-activity in serum during the low sodium period equaled the level of the following control period $(0,64 \mu \mathrm{kat} / \mathrm{l}$ and 0,635 $\mu \mathrm{kat} / \mathrm{l}, \mathrm{p}=0,92)$.
Fig. 2 summarizes the changes in the plasma electrolytes during the feeding trial. Both the plasma sodium and the plasma chloride concentration increased in response to the low sodium diet ( $\mathrm{p}=0.016$ and 0.047$)$ and decreased again when the control diet resumed ( $p=0.008$ and 0.008 ). The plasma potassium concentration did not change when the low sodium diet was introduced $(p=0.30)$ but decreased when the dogs were fed the control diet again $(p=0.016)$. The median plasma potassium concentration was higher during the low sodium period than during the following control period $(4.9 \mathrm{mmol} / 1$ and $4.5 \mathrm{mmol} / \mathrm{l}$, $\mathrm{p}<0,0001)$. The plasma magnesium concentration decreased at the first change in diet $(\mathrm{p}=0.008)$ but not at the second change $(\mathrm{p}=$ 0.69). The plasma calcium concentration (not shown) were unchanged by the decrease as well as the increase in sodium intake $(p=0.74$ and 0.08 ).

\section{Discussion}

The PRA-values in the present study are lower than in other studies both on low sodium intake and on medium/high sodium intake (Villarreal et al. 1990, Nii et al. 1987, Krieger et al. 1990). However, the dogs in the 3 forementioned studies had a lower sodium intake per $\mathrm{kg}$. It is well established that the lower the sodium intake is, the higher is the increase in PRA caused by further reducing the sodium intake. Further, different methodology makes it difficult to compare PRA-values in different studies. Sealey (1991) reported that PRA values varied up to a factor 2.1 when evaluated by different laboratories and kits. A discussion of different methods for measuring PRA including the method used in the present study is given elsewhere (Poulsen \& Nielsen 1993).

The PRA value at the end of the initial con- 
trol period were higher than the PRA level in the final control period. The dogs were not accustomed to the blood sampling procedure, and therefore, might have had a stress-induced renin release via the $\beta$-receptors in the kidney. The results of the present study show that PRA and PAC reach new steady levels within 2 to 3 days after moderate changes in sodium intake. These observations show that 2-3 days after a moderate change in sodium intake, blood sampling for measuring PRA or PAC can take place at any time - the change in diet will not influence the results further.

Villarreal et al. (1990) found that PAC in 5 normal dogs increased from $25 \mathrm{pg} / \mathrm{ml}$ when the dogs were fed approximately $40 \mathrm{mmol}$ $\mathrm{Na}^{+} /$day, to $103 \mathrm{pg} / \mathrm{ml}$ after 1 week and 163 $\mathrm{pg} / \mathrm{ml}$ after 2 weeks of feeding the dogs $<6$ $\mathrm{mmol} \mathrm{Na}^{+} /$day. Krieger et al. (1990) found that PAC averaged $170 \mathrm{pg} / \mathrm{ml}$ in 6 normal dogs on a low sodium diet $\left(8 \mathrm{mmol} \mathrm{Na}^{+} /\right.$day $)$, decreased to undetectable levels when the dogs received $120 \mathrm{mmol} \mathrm{Na}^{+} /$day, and increased to $210 \mathrm{pg} / \mathrm{ml}$ when the low sodium diet resumed. The PAC levels in the present study were higher than in the 2 forementioned studies considering that these 2 studies used more restrictive low sodium diets. This cannot be due to Ang II stimulating the aldosterone synthesis, since the PRA-values if anything were low in the present study.

The high potassium intake of the dogs is a more likely explanation for the high PAC-levels in the present study. The dogs received approximately $95 \mathrm{mmol} \mathrm{K}^{+} /$day whereas the dogs in the studies of Villarreal et al. (1990) and Krieger et al. (1990) received respectively $50-60$ and $30 \mathrm{mmol} \mathrm{K}^{+} /$day. Potassium is a powerfull stimulus for the secretion of aldosterone. The associated sodium retention will restrain the secretion of renin, the end result being an increase in the PAC/PRA ratio. A positive potassium balance and an increase in
PAC/PRA ratio has been reported in humans when reducing the sodium intake at a constant potassium intake (Laragh 1985). Laragh (1985) suggests, that potassium might be retained because of reduced levels of tubular sodium causing reduced activity of the sodiumpotassium exchange mechanism. A positive potassium balance is not necessarily reflected in the plasma potassium concentration. Neither sodium nor potassium balance were evaluated in this study, and it is therefore not known whether there was any potassium retention during the low sodium period. However, the increase in aldosterone/PRA ratio (from 111 to 304), and the decrease in plasma potassium when the low sodium diet was replaced by the control diet, indicated that it might have been the case. Furthermore, the median plasma potassium concentration was higher during the low sodium period than during the following control period. None of the dogs in the present study developed hyperkalemia at any time during the study.

In the only veterinary study published so far on the RAS in dogs with spontaneously developed heart failure, Knowlen et al. (1983) measured the PAC in 23 dogs with CHF. The following PAC-values were obtained (mean $\pm \mathrm{SD}$ ): clinically normal dogs: $76 \pm 33 \mathrm{pg} / \mathrm{ml}$, dogs in New York Heart Association (NYHA) class III: $202 \pm 102 \mathrm{pg} / \mathrm{ml}$ and dogs in NYHA class IV: $420 \pm 223 \mathrm{pg} / \mathrm{ml}$. It appears that the PAC in dogs in NYHA class III was at a level corresponding to the level obtained in the present study, when feeding normal dogs the low sodium diet. On the basis of these findings, the increase in PAC observed by Knowlen et al. (1983) can probably be ascribed in part to a dietary induced increase, since many of the patients in the study, as opposed to the control dogs, were fed low sodium diet for therapeutic reasons (Knowlen et al. 1983). 
The ACE-activity in serum was not changed by the low sodium diet. Fox et al. (1992) found, that dietary sodium deprivation in rats increased the ACE-activity in plasma by $30 \%$, but they also found an inexplicable increase when the rats were sodium loaded. On the basis of these findings and the findings in the present study, it is probably safe to say that the ACE-activity in serum is only influenced to a minor degree by changes in sodium intake. This is not surprising for 2 reasons: the conversion of Ang I to Ang II is quick and is not a rate limiting step, because $\mathrm{ACE}$ is present in a high concentration in vivo (Poulsen \& Jacobsen 1993). Furthermore, ACE is a rather non specific peptidase, and it is therefore likely, that the ACE-activity in serum is regulated according to the need for conversion/degradation of other peptides as well as Ang I.

The increase in the plasma concentrations of sodium and chloride observed when the dogs were fed the low sodium diet is in contrast to the findings in other studies. Usually no change is found in plasma sodium or plasma chloride in response to low sodium diets (Nii et al. 1987, Hamlin et al. 1964). The increased concentrations of sodium and chloride in this study are probably related to the potentiated stimulation of aldosterone that was observed. It is known that hyperaldosteronism is associated with an incease in the plasma concentrations of sodium and chloride.

The decrease in plasma magnesium concentration observed for 3 to 4 weeks after introduction of the low sodium diet is not immediately explainable. It is well known that in ruminants, a sudden change to a high potassium / low sodium feed causes a decrease in plasma magnesium concentration via a decreased enteral absorption of magnesium (Leonhard et al. 1989). Whether or not such a feed has a similar influence on magnesium ab- sorption in monogastric animals remains to be established.

In arterial hypertension in humans there is a beneficial effect on blood pressure associated with dietary potassium supplementation (Cappuccio \& MacGregor 1991). In hypertensive rats, regression of the associated cardiac hypertrophy has also been found in response to dietary potassium (Mervaala et al. 1992). Whether potassium supplementation has beneficial effects in the treatment of CHF is unknown. The findings in the present study indicates that potassium might be a usefull means of decreasing the PRA-levels. This will lead to decreased circulating concentrations of Ang II. Ang II is involved in cardiac hypertrophy and have been shown to cause myocyte injury in rats (Tan et al. 1991). The angiotensin-converting enzyme inhibitors which prevent the formation of angiotensin II have been proven to prolong the life of both humans and dogs with heart failure (Braunwald 1991, Ettinger 1992). Thus, cardioprotective effects might be obtained by feeding dogs with heart failure a diet high in potassium. A more obvious advantage of such a diet is the reduced risk of hypokalaemia in patients treated with diuretics. Further studies are warranted in order to find the appropiate level of potassium in low sodium diets.

\section{Acknowledgements}

The authors wish to thank Ms. K. Faber, Small Anımal Hospital, Department of Clinical Studies, and Mrs. E. Thomsen and Mrs. V. S. Østvedt, Central Laboratory, Dept. of Clinıcal Studies for excellent technical assistance.

Waltham Centre for Pet Nutrition, Leicestershire, England is gratefully acknowledged for providing the diets.

The study was a collaborate study and the financial support of the Danısh Agricultural and Veterınary Research Council project no 13-4633-1 and 13$4661-1$ is gratefully acknowledged 


\section{References}

Braunwald E: ACE inhibitors - A cornerstone of the treatment of heart fallure. New Engl. J. Med. 1991, 325, 351-353.

Cappuccio FP, MacGregor GA: Does potassium supplementation lower blood pressure? A metaanalysis of published trials. J. Hypertens. 1991, 9, 465-473.

Cobb M, Michell AR: Plasma electrolyte concentrations in dogs receiving diuretic therapy for cardiac failure. J. Small Anım. Pract. 1992, 33, 526-529.

Ettinger SJ, Cooperatıve Veterinary Enalaprll (Cove) Study Group: Evaluation of enalapril therapy in dogs with heart failure in a large multicenter study. Proc. 17th WSAVA Vorld Congress 1992, 7-11.

Fox J, Guan S, Hymel AA, Navar $G \cdot$ Dietary $\mathrm{Na}$ and ACE inhibition effects on renal tissue angiotensin I and II and ACE activity in rats. Amer. J. Physiol. 1992, 262, F902-F909.

Hamlin RL, Smith RC, Smith CR, Powers TE: Effects of a controlled electrolyte diet, low in sodium, on healthy dogs Vet. Med./Small Anım. Clin. 1964, 59, 748-751.

Jensen AL, Koch J: Determınation of angiotensinconvertıng enzyme in canıne serum. Clın. Chem. Enzym. Comms. 1992, 4, 311-317

Knowlen GG, Kittleson MD, Nachreiner RF, Eyster $G E$. Comparison of plasma aldosterone concentration among clinical status groups of dogs with chronic heart failure. J Amer. vet med. Ass. 1983, 183, 991-996.

Krieger JE, Liard JF, Cowley Jr AW: Hemodynamıcs, fluid volume, and hormonal responses to chronic high-salt intake in dogs. Amer. J. Physiol. 1990, 259, H1629-H1636.

Larahg JH: Atrial natriuretıc hormone, the renın-aldosterone axis, and blood pressure-elektrolyte homeostasis. New Engl. J. Med. 1985, 313, 13301340.

Legrand-Defretın $V$ : Energy requirements of cats and dogs - what goes wrong. Int J Obesity 1994, 18 (Suppl. 1), S8-S13.

Leonhard S, Martens $H$, Gabel $G$ : New aspects of magnesium transport in ruminants. Acta vet. scand. 1989, suppl 86, 146-151.

Mervaala EMA, Himberg J, Laakso J, Tuomainen P, Karppanen $H$ : Beneficial effects of a potassiumand magnesium enriched salt alternative. Hypertension 1992, 19, 535-540.

Nı T, Fouad-Tarazı FM, Ferrarlo CM, Bravo EL, $C$ zerska $B$. Changes in hemodynamics and myo- cardial contractility durıng chronıc sodium depletion in conscious dogs. Hypertension 1987, 9 (suppl III), III-176 - III-180.

Pensinger RR: Dietary control of sodium intake in spontaneous congestive heart failure in dogs. Vet. Med./Small Anımal Clın. 1964, 59, 752-757.

Poulsen K, Jacobsen J: Enzymic reactions of the renin-angiotensın system. In: Robertson JIS, N1cholls MG (eds). The renın angiotensin system. Gover Medical Publishers, London 1993.

Poulsen K, Jørgensen J: An easy radioımmunological microassay of renin activity, concentration and substrate in human and animal plasma and tissues based on angiotensin I trapping by ant1body. J clin. Endocr. Metab. 1974, 39, 816-825.

Poulsen K, Nielsen AH: The measurement of renin. In: Robertson JIS, Nicholls MG (eds): The renın angiotensin system Gover Medical Publishers, London 1993.

Ross JN Jr: Heart failure. In: Lewis LD, Morris ML $\mathrm{Jr}$ (eds): Small anımal clinical nutrition, 2nd ed. Mark Morris Associates, Topeka, Texas 1984.

Sealey JE. Plasma renin activity and plasma prorenin assays. Clin. Chem. 1991, 37, 1811-1819.

Tan L, Jalıl JE, Pıck R, Janıckı JS, Weber KT: Cardiac myocyte necrosis induced by angiotensin II. Circulation Research 1991, 69, 1185-1195.

Villarreal D, Freeman RH, Brands $M W$ : ANF and postprandial control of sodium excretion in dogs with compensated heart fallure. Amer. J. Physiol. 1990, 258, R232-R239.

Watkins L Jr, Burton JA, Haber E, Cant JR, Smith $F W$, Barger $A C$. The renin-angiotensin-aldosterone system in congestive falure in conscious dogs. J. clın Invest. 1976, 57, 1606-1617.

\section{Sammendrag}

Nogle effekter af en diot med lavt natrum indhold og højt kalıum indhold på renin-angiotensın systemet og plasma elektrolyt koncentratıoner hos raske hunde.

Otte normale beagle hunde indtog $0.7 \mathrm{mmol}$ $\mathrm{Na}^{+} / \mathrm{kg} / \mathrm{dag} \mathrm{i}$ én 5 ugers periode og $4.0 \mathrm{mmol}$ $\mathrm{Na}^{+} / \mathrm{kg} / \mathrm{dag}$ i en 3 ugers kontrol perıode før og én efter lav-natrium perioden. Hundene indtog $6.8 \mathrm{mmol}$ $\mathrm{K}^{+} / \mathrm{kg} /$ dag i hele perioden.

Medianværdien af plasma renın aktıviteten (PRA) og plasma aldosteron koncentrationen (PAC) var højere 1 lav-natrium perioden end 1 den efterfølgende kontrol periode $(0.67$ versus $0.28 \mathrm{ng} / \mathrm{ml} / \mathrm{h}, P<$ $0.0001)$ og (204 versus $31 \mathrm{pg} / \mathrm{ml}, P<0.0001)$. PRA og 
PAC indstıllede sıg hurtıgt på et nyt stabılt niveau efter ændret natrium indtag. Angıotensın-convertıng enzyme (ACE) aktıviteten ændrede sig lkke som følge af det ændrede natrıum indtag.

Plasma koncentrationerne af natrium og klorid var højere 1 lav-natrium perıoden sammenlıgnet med de to kontrol perıoder. Dette skyldtes muligvis en ind1rekte effekt af det høje kalıum indtag. Kalıum fører til en forøget sekretion af aldosteron og dermed til en $\emptyset$ get retention af natrium og klorid 1 nyrerne. Mulige betydninger af et højt kalıum indhold 1 lavnatrium diæter diskuteres.

(Accepted December 22, 1993).

Reprints may be requested from: H.D. Pedersen, Small Animal Hospital, Department of Clinıcal Studies, The Royal Veterınary and Agricultural Unıversity, Bulowsvej 13, DK-1870 Frederıksberg C, Denmark. 